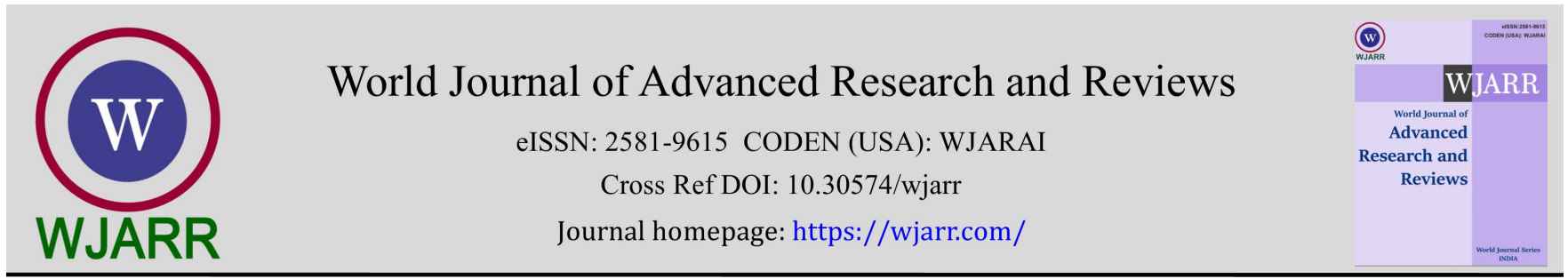

(RESEARCH ARTICLE)

Check for updates

\title{
Antibiotic susceptibility of four Enterobacteriaceae strains (Enterobacter cloacae, Citrobacter freundii, Salmonella typhi and Shigella sonnei) isolated from wastewater, surface water and groundwater in the equatorial zone of Cameroon (Central Africa)
}

Awawou Manouore Njoya 1, Yves Poutoum Yogne 1, Jean Samuel Eheth 1, Edith Brunelle Mouafo Tamnou 1, Claire Stéphane Metsopkeng ${ }^{1}$, Olive Vivien Noah Ewoti ${ }^{1}$, Antoine Tamsa Arfao ${ }^{1}$, Luciane Marlyse Moungang ${ }^{1}$, Paul Alain Nana ${ }^{2}$, Sylvie Chinche Belengfe ${ }^{3}$, Estelle Masseret ${ }^{4}$, Télesphore Sime-Ngando ${ }^{5}$ and Moïse Nola ${ }^{1}{ }^{*}$

1 University of Yaounde I, Faculty of Sciences, Laboratory of Hydrobiology and Environment, P.O. Box 812 Yaounde, Cameroon.

2 Department of Oceanography and Limnology, Institute of Fisheries and Aquatic Sciences, University of Douala, P.O. Box 7236, Douala, Cameroon.

${ }^{3}$ Department of Fisheries and Aquatic Resources Management, Faculty of Agriculture and Veterinary Medicine, University of Buea, Cameroon.

${ }^{4}$ MARBEC, University of Montpellier, IRD, Ifremer, CNRS, Montpellier, France.

${ }^{5}$ Laboratory "Microorganisms : Genome and Environment (LMGE)", University of Clermont Auvergne, Aubière Cedex, France.

World Journal of Advanced Research and Reviews, 2021, 11(01), 120-137

Publication history: Received on 26 May 2021; revised on 10 July 2021; accepted on 13 July 2021

Article DOI: https://doi.org/10.30574/wjarr.2021.11.1.0303

\begin{abstract}
The health problems caused waterborne pathogens bacteria belonging to the Enterobacteriaceae family are aggravated by the rise of antimicrobial resistant bacteria phenomenon. This has been identified as one of the biggest global health challenges. The present study aims to make a comparative approach of the sensitivity/resistance to antibiotics of 4 Enterobacteriaceae Enterobacter cloacae, Citrobacter freundii, Salmonella typhi and Shigella sonnei isolated from wastewater, streams and groundwater in Yaounde town (Cameroon, Central Africa). Bacteria were isolated using standard methods their identification using the API 20E systems. The antibiogram tests were carried out using the Müller-Hinton antibiotic disc diffusion method. Results showed that inhibition diameters of antibiotic varied (P<0.05) with respect to the bacterial species on one hand, and with respect to the type of water harbored cells on the other hand. The proportion of bacterial strains of each isolated species, and which were sensitive or resistant varied from one antibiotic to another within the same antibiotics family. For $\beta$-lactams tested, no E. cloacae strain has been sensitive. The proportion of sensitive strains of other species varied between $5.88 \%$ and $23.53 \%$. For the 2 aminoglycosides tested, $5.88 \%$ of the strains of each isolated species were resistant to gentamycin. Of the 3 quinolones tested, all strains of $E$. cloacae and $C$. freundii isolated were fully resistant to Norfloxacin and of Ofloxacin. For the 3 Sulfonamides+trimethoprim, all strains of $C$. freundii and $S$. typhi isolated were resistant to Nurofurantoin and Fosfomycin. Most of bacteria strains isolated in wastewater and surface water were resistant to all the antibiotics tested. Many bacterial strains tested were multi-resistant. This multidrug resistance was more marked in E. cloacae and $C$. freundii species isolated from wastewater and surface water. This represents a health risk for humans and the aquatic environment.
\end{abstract}

Keywords: Water system; Cell's abundance; Enterobacteriaceae species; Antibiotic susceptibility; Abiotic factor

\footnotetext{
* Corresponding author: Moïse Nola

University of Yaounde I, Faculty of Sciences, Laboratory of Hydrobiology and Environment, P.O. Box 812 Yaounde, Cameroon. 


\section{Introduction}

A significant proportion of bacteria isolated in freshwater are of the Enterobacteriaceae family. Their abundance in the intestine, their mobility and the frequent acquisition of antibiotic resistance mechanisms explain why they are the most involved bacteria in human infectious pathology [1]. Most effluents from municipal, industrial, veterinary activities, hospital and secondary treatment sources harbored enterobacteria [2, 3]. These discharges often lead to the contamination of natural aquatic environments $[4,5]$. In addition, antibiotics and their metabolites released have a direct impact on microorganisms in the environment [6-8].

Antibiotics can be classified on the basis of their mechanisms action and the mechanisms of the antimicrobial resistance, although resistance mechanism of individual antibiotics has been indicated [9-11]. Based on of the mechanisms of their action, they can be grouped in antibiotics targeting cell wall, inhibitors of protein biosynthesis, inhibitors of DNA replication and folic acid metabolism inhibitors. Based on of the mechanisms of the antimicrobial resistance, there is two main ways: the antibiotic inactivation and the prevention of accumulation of antimicrobials either by decreasing uptake or increasing efflux of the antimicrobial from the cell i.e., changes in outer membrane permeability.

According to Li et al. [12], the efficacy of antimicrobials in general are influenced by many factors including: a)-the bacterial status (susceptibility and resistance, tolerance, persistence, biofilm) and inoculum size; b)-the antimicrobial concentrations [mutant selection window and sub-inhibitory concentration]; c)-the host factors. Bacterial status is one of the determinants for antimicrobial activity. The bacterial phenotypes are different under antibiotic exposure, such as susceptibility, resistance, tolerance, and persistence [13]. Antibiotic resistance happens when germs develop the ability to defeat the drugs designed to kill them. This does not mean the body is becoming resistant to antibiotics; it is that bacteria have become resistant to the antibiotics. The germs are not killed and continue to grow. This phenomenon has the potential to affect people at any stage of life, making it one of the world's most urgent public health problems [14]. Several works conducted on the resistant profile of bacteria isolated from hospital environments and belonging to the Enterobacteriaceae family are resistant to different families of antibiotics [15].

The origins of antibiotic resistance could be resulted from genetic jugglery during which random mutations of the genes encoding the enzymes can give rise to modified catalysts with increasingly extended spectra of resistance and intrinsic resistance which refers to the existence of genes in bacterial which genomes that could generate a resistance phenotype $[16,17]$. Other origin is from resistosme. This refers to all the antibiotic resistance genes in communities of both pathogenic and non-pathogenic bacteria or all of the resistance genes in an organism, how they are inherited, and how their transcription levels vary to defend against pathogens like viruses and bacteria [18-20]. For this, bacterial strains resistant to antibiotics can be isolated by plating environmental bacteria on antibiotic-containing media since most possess genes encoding resistance to the compounds that they produce [21]. Bacteria can thus be naturally resistant to particular antibiotics; others, however, develop resistance through genetic mutations induced via exposure to antibiotics. Antibiotic resistance also has the opportunity to spread, given the ease of exchanging the material relating to resistance between bacteria species [22]. Antibiotic resistance genes isolated are usually not present in pathogenic bacteria, nor do they appear in the antibiotic era, but rather originate from antibiotic-producing microbes or those that cohabit with them in the environment [23].

Enterobacteriaceae are enzyme producers and possess other mechanisms of resistance to many antibiotics [24, 25]. The high concentration of these germs in the gastrointestinal tract favours the exchange and dissemination of resistant genes in the environment [26, 27], particularly in domestic and hospital wastewater, and sometimes even in groundwater and surface water. In these different water systems, antibiotic susceptibility of bacteria can be impacted by many environmental factors $[28,29]$.

Each year, waterborne diseases afflict hundreds of millions of people, primarily those living without safe, accessible water in developing countries. Waterborne diseases are illnesses caused by microscopic organisms that are ingested through contaminated water or by coming in contact with feces, with diarrhea as the central symptom [30]. Some of waterborne pathogens are ubiquitous [31]. Most of the concerned bacteria belongs to the Enterobacteriaceae family $[32,33]$. The situation is aggravated by the rise of antimicrobial resistant bacteria which has been identified as one of the biggest global health challenges [34].

Few studies have been done on the antibiotic susceptibility profile of Enterobacteriaceae species from different types of hydrosystems in the same geographical area. The present study aims to make a comparative approach of the sensitivity/resistance to antibiotics of 4 Enterobacteriaceae Enterobacter cloacae, Citrobacter freundii, Salmonella typhi and Shigella sonnei isolated from wastewater, streams and groundwater of Yaounde town (Cameroon, Central Africa). 


\section{Material and methods}

\subsection{Study area}

Yaounde which is the capital of Cameroon. It is located $300 \mathrm{~km}$ from the Atlantic coast, between $3^{\circ} 5^{\prime}$ North latitude and $11^{\circ} 31^{\prime}$ East longitude [35]. The climate is equatorial, characterised by the alternation of two dry seasons and two rainy seasons: a long dry season from December to mid-March, a short rainy season from mid-March to June, a short dry season from July to August and a long rainy season from September to November. The annual average temperature is $23.5^{\circ} \mathrm{C}$, varying between 16 and $31^{\circ} \mathrm{C}$ depending on the season, and $1650 \mathrm{~mm}$ of water per year. The city's hydrographic network is very dense and essentially composed of the Mfoundi river and its tributaries. Some districts and hospitals in Yaounde are equipped with wastewater treatment plants. The study was conducted in November 2020 (during the long rainy season).

\subsection{Sampling sites and water sampling}

Four kinds of sampling sites have been chosen: wastewater of the University Hospital Centre (UHC), wastewater from residential quarters, surface water, and groundwater. The wastewater of the UHC included wastewater collector of the UHC laundry room coded Sw1, wastewater collector of the surgical room of the UHC coded Sw2, and wastewater from the laundry and the surgery room of the UHC coded Sw3.

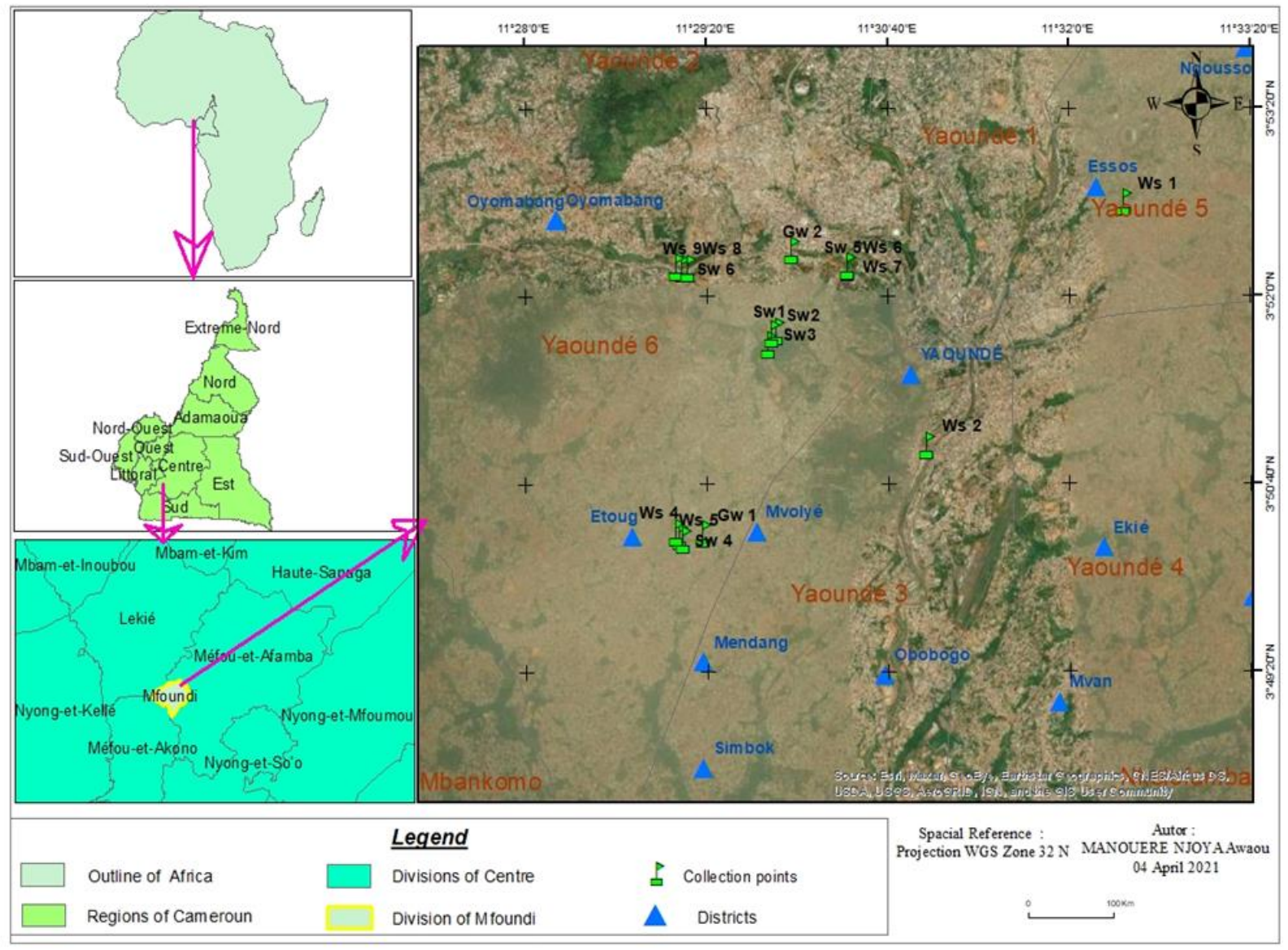

Figure 1 Geographical location of the study area and representation of the sampling points Sampling

(Source: Https//d-maps.com/pays.php?num_pay=16\&lang=fr)

The wastewater from residential quarters included that from Biyem-Assi quarter wastewater treatment plant coded Sw4, that from Messa quarter wastewater treatment plant coded Sw5, and that from Cité Verte quarter wastewater treatment plant coded Sw6. The three wastewater treatment plants are waste stabilization ponds. The surface water included 9 sampling points: upstream, landing and downstream of the Mfoundi river coded Ws1, Ws2 and Ws3 respectively. 
Table 1 Characteristics of sampling points

\begin{tabular}{|c|c|c|c|c|}
\hline \multirow{2}{*}{$\begin{array}{l}\text { Hydro- } \\
\text { systems }\end{array}$} & \multirow{2}{*}{$\begin{array}{l}\text { Sampling } \\
\text { station }\end{array}$} & \multicolumn{2}{|c|}{ Geographical coordinates } & \multirow{2}{*}{ Description } \\
\hline & & Latitude (N) & Longitude (E) & \\
\hline \multirow{3}{*}{$\begin{array}{l}\text { Hospital } \\
\text { waste- } \\
\text { water (Sw) }\end{array}$} & Sw1 & $3^{\circ} 86^{\prime} 25,82^{\prime \prime}$ & $11^{\circ} 49^{\prime} 74,88^{\prime \prime}$ & $\begin{array}{l}\text { Waste water collector of the UHC laundry } \\
\text { room }\end{array}$ \\
\hline & Sw2 & $3^{\circ} 86^{\prime} 22,25^{\prime \prime}$ & $11^{\circ} 49^{\prime} 69,86^{\prime \prime}$ & $\begin{array}{l}\text { Wastewater collector of the surgical room of } \\
\text { the University Hospital }\end{array}$ \\
\hline & Sw3 & $3^{\circ} 86^{\prime} 09,47^{\prime \prime}$ & $11^{\circ} 496^{\prime} 49,6^{\prime \prime}$ & $\begin{array}{l}\text { Collector receiving wastewater from the } \\
\text { laundry and the surgery room of the } \\
\text { University Hospital }\end{array}$ \\
\hline \multirow{3}{*}{$\begin{array}{l}\text { Domestic } \\
\text { waste- } \\
\text { water }(\mathrm{Sw})\end{array}$} & Sw4 & $3^{\circ} 83^{\prime} 83,33^{\prime \prime}$ & $11^{\circ} 48^{\prime} 56,23^{\prime \prime}$ & $\begin{array}{l}\text { Wastewater discharge point of the Biyem- } \\
\text { Assi wastewater treatment plant }\end{array}$ \\
\hline & Sw5 & $3^{\circ} 87^{\prime} 02,12^{\prime \prime}$ & $11^{\circ} 50^{\prime} 63,2^{\prime \prime}$ & $\begin{array}{l}\text { Wastewater discharge point of the Messa } \\
\text { wastewater treatment plant }\end{array}$ \\
\hline & Sw6 & $3^{\circ} 87^{\prime} 00,3^{\prime \prime}$ & $11^{\circ} 48^{\prime} 59,16^{\prime \prime}$ & $\begin{array}{l}\text { Wastewater discharge point of the Cité Verte } \\
\text { wastewater treatment plant }\end{array}$ \\
\hline \multirow[t]{9}{*}{$\begin{array}{l}\text { Surface } \\
\text { water (Ws) }\end{array}$} & Ws1 & $3^{\circ} 87^{\prime} 77,22^{\prime \prime}$ & $11^{\circ} 54^{\prime} 01,3^{\prime \prime}$ & $\begin{array}{l}\text { Upstream of the Mfoundi river, close to } \\
\text { houses and where domestic waste is dumped }\end{array}$ \\
\hline & Ws2 & $3^{\circ} 84^{\prime} 90,11^{\prime \prime}$ & $11^{\circ} 51^{\prime} 59,68^{\prime \prime}$ & $\begin{array}{l}\text { Landing on the Mfoundi river, receiving } \\
\text { domestic waste }\end{array}$ \\
\hline & Ws3 & $3^{\circ} 80^{\prime} 36,78^{\prime \prime}$ & $11^{\circ} 50^{\prime} 93,25^{\prime \prime}$ & $\begin{array}{l}\text { Downstream of the Mfoundi river, near a } \\
\text { brewery company }\end{array}$ \\
\hline & Ws4 & $3^{\circ} 83^{\prime} 87,69^{\prime \prime}$ & $11^{\circ} 48^{\prime} 50,98^{\prime \prime}$ & $\begin{array}{l}\text { Upstream of the Biyeme tributary which } \\
\text { receives wastewater from the Biyem-Assi } \\
\text { wastewater treatment plant }\end{array}$ \\
\hline & Ws5 & $3^{\circ} 83^{\prime} 78,86^{\prime \prime}$ & $11^{\circ} 48^{\prime} 60,18^{\prime \prime}$ & $\begin{array}{l}\text { Downstream of the Biyeme tributary which } \\
\text { receives wastewater from the Biyem-Assi } \\
\text { wastewater treatment plant }\end{array}$ \\
\hline & Ws6 & $3^{\circ} 87^{\prime} 02,55^{\prime \prime}$ & $11^{\circ} 50^{\prime} 62,68^{\prime \prime}$ & $\begin{array}{l}\text { Upstream of the Mingoa tributary which } \\
\text { receives wastewater from the Messa } \\
\text { wastewater treatment plant }\end{array}$ \\
\hline & Ws7 & $3^{\circ} 87^{\prime} 01,94^{\prime \prime}$ & $11^{\circ} 50^{\prime} 63,4^{\prime \prime}$ & $\begin{array}{l}\text { Downstream of the Mingoa tributary which } \\
\text { receives wastewater from the Messa } \\
\text { wastewater treatment plant }\end{array}$ \\
\hline & Ws8 & $3^{\circ} 87^{\prime} 00,83^{\prime \prime}$ & $11^{\circ} 48^{\prime} 66,31^{\prime \prime}$ & $\begin{array}{l}\text { Upstream of the Abiergué tributary which } \\
\text { receives wastewater from the Cité Verte } \\
\text { plant }\end{array}$ \\
\hline & Ws9 & $3^{\circ} 87^{\prime} 01,42^{\prime \prime}$ & $11^{\circ} 48^{\prime} 52,98^{\prime \prime}$ & $\begin{array}{l}\text { Downstream of the Abiergué tributary which } \\
\text { receives wastewater from the Cité Verte } \\
\text { plant }\end{array}$ \\
\hline \multirow[t]{2}{*}{$\begin{array}{l}\text { Ground- } \\
\text { water }(\mathrm{Gw})\end{array}$} & Gw1 & $3^{\circ} 83^{\prime} 85,53^{\prime \prime}$ & $11^{\circ} 48^{\prime} 85,19^{\prime \prime}$ & $\begin{array}{l}\text { Covered well located near the Biyem-Assi } \\
\text { wastewater treatment plant and houses }\end{array}$ \\
\hline & Gw2 & 387'20,89" & $11^{\circ} 49^{\prime} 94,01^{\prime \prime}$ & $\begin{array}{l}\text { Developed spring located upstream of the } \\
\text { Mingoa tributary }\end{array}$ \\
\hline
\end{tabular}

The Biyeme tributary upstream coded Ws4 and downstream coded Ws5, the Mingoa tributary upstream coded Ws6 and downstream coded Ws7, and the Abiergue tributary upstream coded Ws8 and downstream coded Ws9 were also 
included. The groundwater sampling points included one wells coded Gw1 and one springs coded Gw2. In total, 17 sampling sites were chosen for this study. They are presented in Figure 1 and their characteristics and geographic coordinates are indicated in Table 1.

Water sampling was performed according to the method of Rodier et al. [36]. For the physicochemical analyses, the samples were collected in $1000 \mathrm{~mL}$ polyethylene bottles previously rinsed with the sample water; while the samples for bacteriological analyses, around $300 \mathrm{~mL}$ were collected in $500 \mathrm{~mL}$ sterile glass bottles. The samples were then brought back to the laboratory in a refrigerated chamber $\left(4^{\circ} \mathrm{C}\right)$ for analysis.

\subsection{Physicochemical analysis}

Physicochemical parameters were analyzed according to the techniques recommended by Rodier et al. [36] and APHA [37]. The parameters considered for this study were: temperature, $\mathrm{pH}$, electrical conductivity, nitrates and orthophosphates. Temperature, $\mathrm{pH}$ and electrical conductivity were measured in the field using a HANNA/HI 9829 multimeter; while nitrates and orthophosphates were measured in the laboratory using a DR/2000 HACH spectrophotometer.

\subsection{Bacteriological analysis}

\subsubsection{Isolation of Heterotrophic aerobe bacteria (HAB) and Enterobacteriaceae}

Heterotrophic aerobe bacteria (HAB) were isolated on standard plate count agar. The isolation and counting of the total Enterobacteriaceae were performed on Drigalski Lactose agar culture medium [38]. The agar culture medium Methylene Blue Eosin (EMB) (Biokar) was used for the isolation of Enterobacter cloacae and Citrobacter freundii [39, 40] and the agar culture medium Salmonella-Shigella (SS) (Biokar) was used for the isolation of Salmonella typhi and Shigella sonnei [41-43]. Plate count technique was used. A volume of $0.1 \mathrm{~mL}$ of each sample or after dilution was taken with a micropipette and plated on the surface of the agar contained in Petri dishes. Incubation was done at laboratory temperature $\left(25^{\circ} \mathrm{C} \pm 2^{\circ} \mathrm{C}\right)$ for 5 days $\mathrm{HAB}$, and at $37^{\circ} \mathrm{C}$ for 24 hours for others $[36,43]$. All the analyses were done in triplicate.

\subsubsection{Macroscopic examination and identification of Enterobacteriaceae species}

After the incubation period, colonies were counted in the different Petri dishes based on their characteristics. On EMB culture medium, Enterobacter will appear pink-colored colonies without a sheen whereas Citrobacter will appear brown colored colonies without any metallic sheen $[39,40]$. On the SS culture medium Salmonella will not ferment lactose, but produce hydrogen sulfide $\left(\mathrm{H}_{2} \mathrm{~S}\right)$ gas, and their colonies will appear colorless with black centers, whereas Shigella do not ferment lactose or produce hydrogen sulfide gas, and their colonies will be colorless [41-43]. After enumeration of the colony forming units based on the cultural characteristics of the bacteria, the cells of each colony were recultured on standard (non-selective) agar, this agar having been solidified in the sloping test tubes. After Gram coloration, biochemical tests were then performed using the API 20 E systems (Biomerieux) [44].

\subsubsection{Antibiogram tests}

The antibiogram tests were done by the diffusion method of antibiotic discs on Muller Hinton medium according to the recommendations of the "Antibiogram Committee of the French Microbiology Society" (AC-FMS) [45]. Antibiotic molecules were chosen according to their sensitivity and/or resistance to Enterobacteriaceae, but also according to their availability in the market.

A total of 20 antibiotic molecules belonging to four families were used in the susceptibility testing galleries. The family of $\beta$-lactams (Amoxicillin; Amoxicillin + Clavulanic acid; Imipenem; Meropenem; Ticarcillin; Piperacillin; Piperacillin/tazobactam; Ceftriaxon; Cefepim; Cefuroxim; Cefoxitim; Ceftazidim), the family of Quinolones (Ciprofloxacin; Norfloxacin; Ofloxacin), the family of Aminoglycosides (Amikacin; Gentamycin), and the family of Sulfonamides+Trimethoprim and others (Trimethoprim/Sulfamethoxazole; Nurofurantoin; Fosfomycin).

Inhibition diameters were measured using the caliper and the results were scored as either resistant, sensitive or intermediate according to the interpretation of CA-SFM [46, 47].

\subsection{Data analysis}

The abundances of the bacteria isolated were expressed per volume of $100 \mathrm{ml}$ of water. The values of physicochemical parameters and those of bacterial abundances were illustrated by histograms plotted using Excel 2016 software. The 
Kruskal-Wallis and Mann-Whitney tests were carried out using SPSS software version 25.0 to compare the inhibition diameters of antibiotic against bacterial species in each types of water.

\section{Results and discussion}

\subsection{Physicochemical parameters}
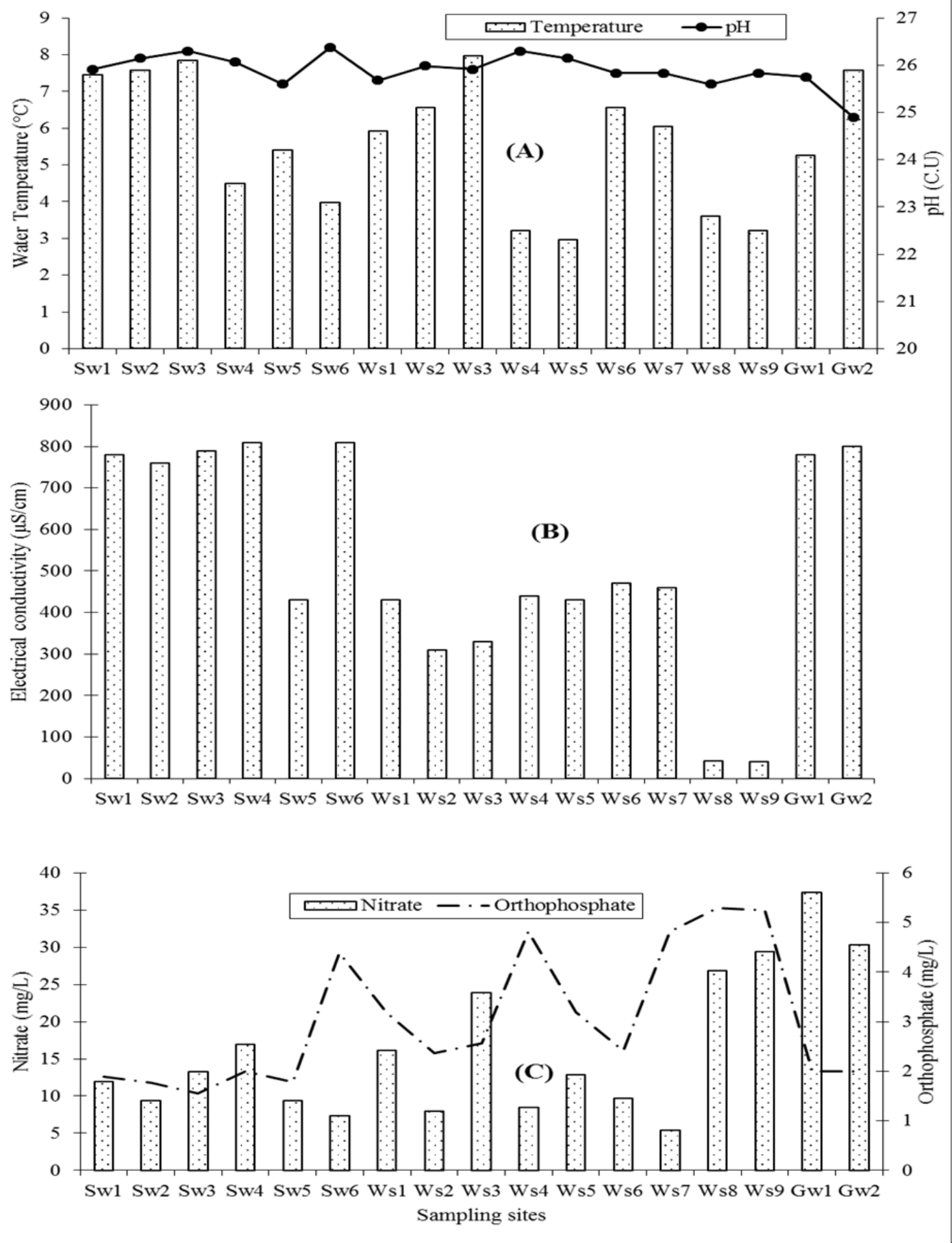

Figure 2 Variation of physicochemical parameters in the different sampling points (A: variation of temperature and $\mathrm{pH}$; B: variation of electrical conductivity; C: variation of the concentration in nitrates and orthophosphates) 
The mean values of the physicochemical parameters are represented on Fig.2. It appears that these parameters values varied from one point to another. The temperature values varied between 22.8 and $26.2^{\circ} \mathrm{C}$, with the lowest value recorded at the surface water station Ws5 and the highest value at station Ws3 (Fig. 2A). This variation is much more pronounced in surface water than in wastewater and groundwater and this could be explained by variations in the ambient temperature of the environment. According to Merhabi et al. [48], the temperature of surface water is affected by fluctuations in precipitation and seasonal temperatures. Wastewater temperature depends on organic load while groundwater temperature depends on latitude and altitude. Water temperature is an important factor as it governs almost all physicochemical and biological reactions. An abrupt change in this parameter leads to the disturbance of the water ecosystem balance [49]. The pH values ranged from 6.3 to 8.2 C.U. with the lowest value recorded in springs Gw2 and the highest wastewater station Sw6 (Fig. 2A). It is observed that pH of the sampled groundwater is slightly acidic while that of the wastewater and surface water is slightly basic. This has also been noted by Diane et al. [50]. According to Noah et al. [51], pH between 6.0 and 8.5 U.C. is favorable for the expression of biological potentials of several groups.

Electrical conductivity fluctuated between 41 and $810 \mu \mathrm{S} / \mathrm{cm}$ with the lowest value recorded at the surface water station Ws9 and the highest at stations Sw4 and Sw6 (Fig. 2B). The nitrate content fluctuated from point to point between 5.4 and $37.4 \mathrm{mg} / \mathrm{L}$. The lowest value was recorded at station Ws7 while the highest is recorded in wells Gw1 (Fig. 2C). Regarding orthophosphate content, the values varied between 1.56 and $5.29 \mathrm{mg} / \mathrm{L}$ with the lowest value recorded at wastewater station Sw3 and the highest at surface water station Ws8 (Fig. 2C). According to Rodier et al. [36], the presence of phosphates in natural waters is linked to the nature of the terrain crossed, the decomposition of organic matter and the use of detergents. As organic pollution is noticeable when the orthophosphate content is higher than 0.5 $\mathrm{mg} / \mathrm{L}$, these waters are polluted [36].

\subsection{Bacterial abundance}

The variation in the abundance of heterotrophic aerobe bacteria (HAB) and Enterobacteriaceae is presented in Fig. 3. In wastewaters samples from the University Hospital Centre (UHC), the abundance of heterotrophic aerobe bacteria (HAB) varied from $18.4 \times 10^{3}$ to $463 \times 10^{3} \mathrm{CFU} / 100 \mu \mathrm{L}$ and that of Enterobacteriaceae varied from $0.95 \times 10^{3}$ to $20.8 \times 10^{3}$ $\mathrm{CFU} / 100 \mu \mathrm{L}$. For the wastewaters from the residential quarters, the abundance of heterotrophic aerobe bacteria (HAB) varied from $60.4 \times 10^{3}$ to $212 \times 10^{3} \mathrm{CFU} / 100 \mu \mathrm{L}$ and that of Enterobacteriaceae varied from $0.5 \times 10^{3}$ to $17.8 \times 10^{3} \mathrm{CFU} / 100$ $\mu \mathrm{L}$. In the surface waters, they varied from $144 \times 10^{3}$ to $401 \times 10^{3} \mathrm{CFU} / 100 \mu \mathrm{L}$ for HAB and from $6.5 \times 10^{3}$ to $38 \times 10^{3}$ $\mathrm{CFU} / 100 \mu \mathrm{L}$ for Enterobacteriaceae. In groundwater sampled, abundance of HAB varied from $4.7 \times 10^{3}$ to $12 \times 10^{3}$ $\mathrm{CFU} / 100 \mu \mathrm{L}$ for $\mathrm{HAE}$ and from $0.3 \times 10^{3}$ to $0.6 \times 10^{3}$ for the Enterobacteriaceae (Fig. 3).

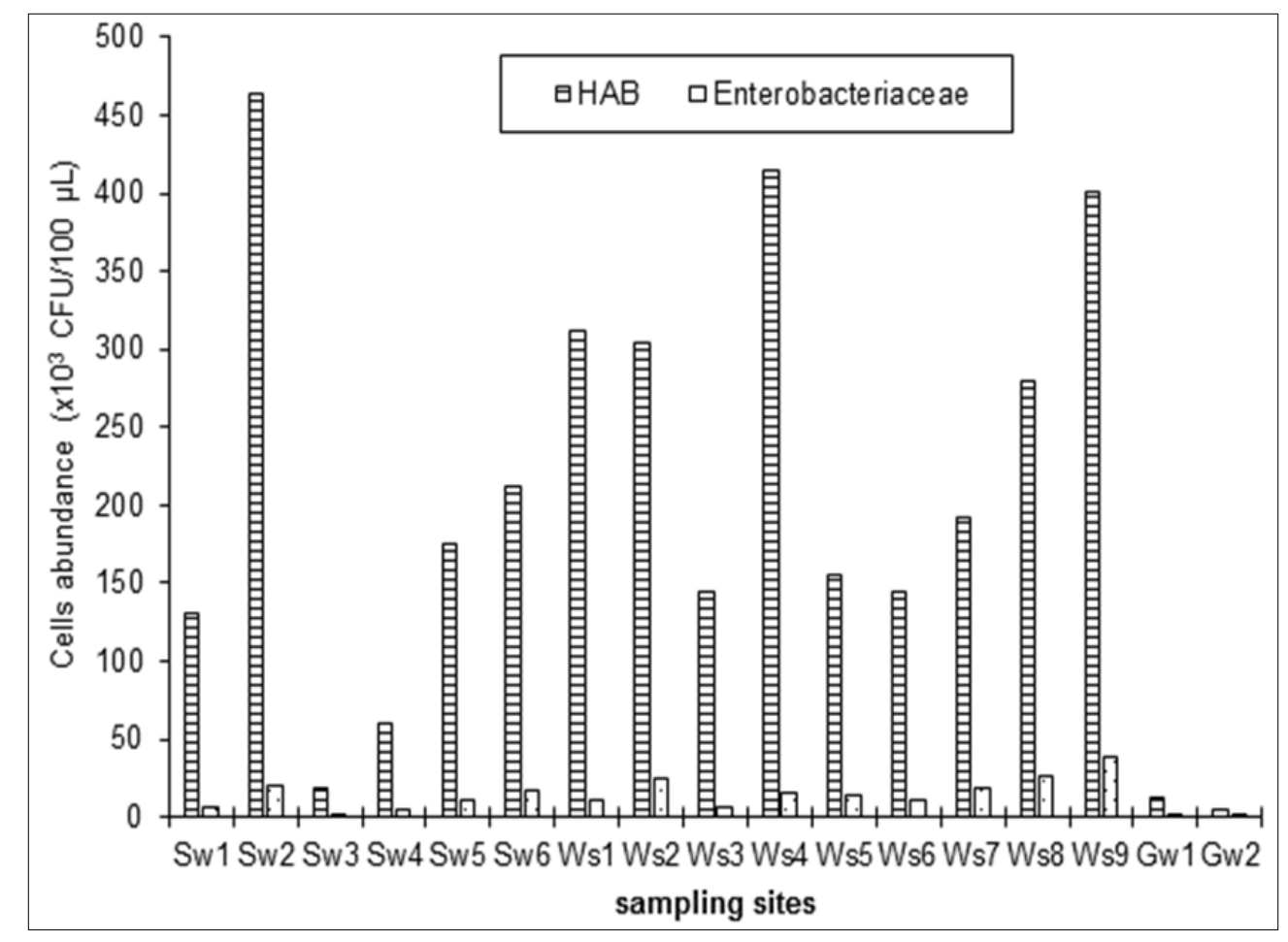

Figure 3 Variation with respect to the sampling sites of the abundance of the total heterotrophic aerobe bacteria (HAB) and Enterobacteriaceae 
The mean values of the abundance of cells species are presented on Fig. 4. It is noted E. cloacae abundance fluctuated between $1 \mathrm{CFU} / 100 \mu \mathrm{L}$ and $30 \mathrm{CFU} / 100 \mu \mathrm{L}$. The lowest value recorded in springs Gw2 and the highest at wastewater station Sw5 (Fig. 4). For $C$. freundii, its abundance varied between $1 \mathrm{CFU} / 100 \mu \mathrm{L}$ and $112 \mathrm{CFU} / 100 \mu \mathrm{L}$. The lowest value was recorded in springs Gw2 and the highest at surface water station Ws8 (Fig. 4). The abundance of $S$. sonnei ranged from $2 \mathrm{CFU} / 100 \mu \mathrm{L}$ to $198 \mathrm{CFU} / 100 \mu \mathrm{L}$. The lowest value was recorded in the springs Gw2 and the highest value at the surface water station Ws2 (Fig. 4). For S. typhi, the abundance ranged from $1 \mathrm{CFU} / 100 \mu \mathrm{L}$ to $44 \mathrm{CFU} / 100 \mu \mathrm{L}$. The lowest value was recorded in GW1 and wastewater station Sw3 and the highest at station Sw5 (Fig. 4).

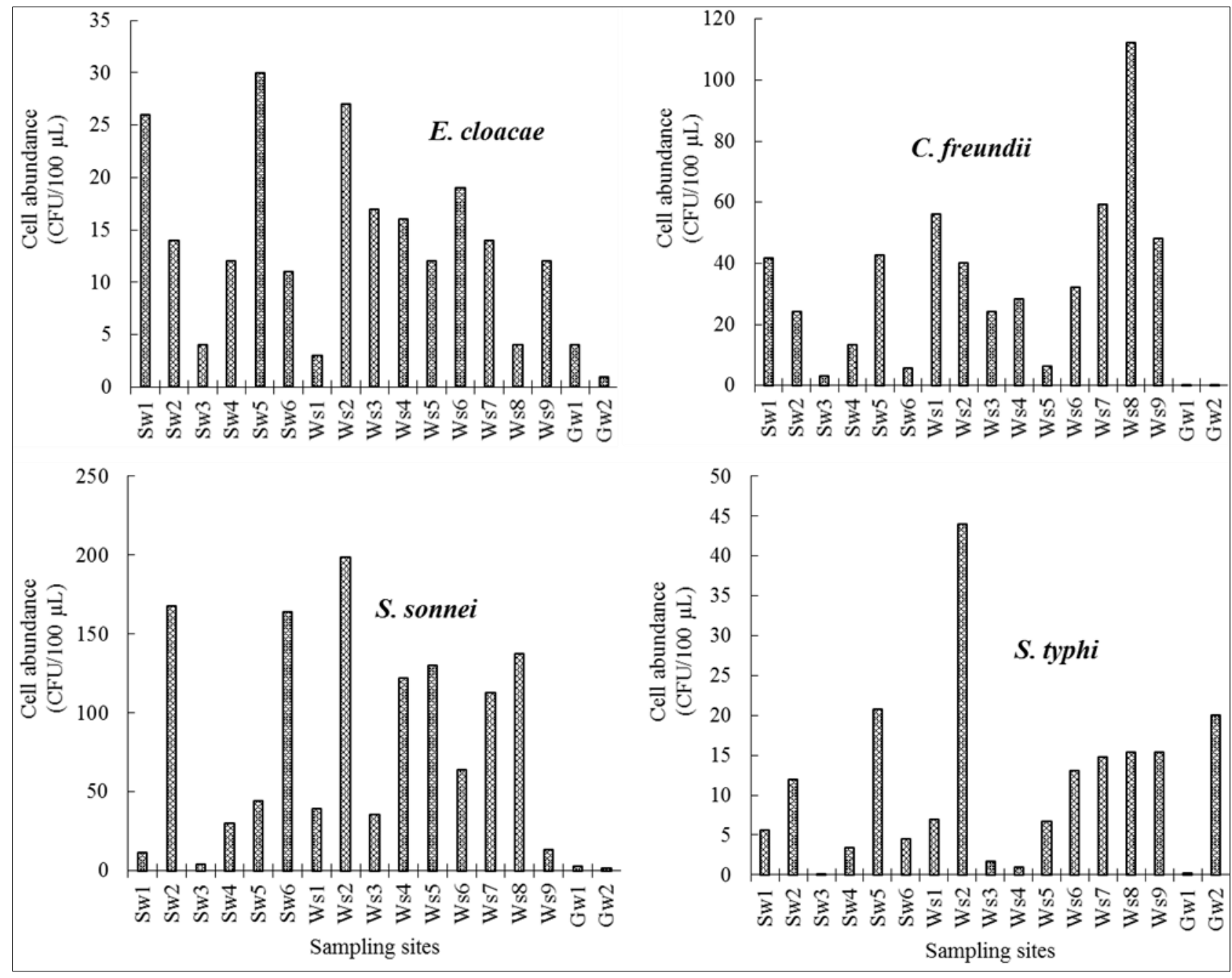

Figure 4 Abundance of Enterobacteriaceae species (E. cloacae, C. freundii, S. sonnei and S. typhi) isolated in the different sampling points

The presence of these Enterobacteriaceae in the different sampling stations indicate faecal pollution as these species are generally isolated in the stools and urine of people with severe pathologies. The composition of these ecosystems reflects the characteristics of bacteria released by humans, mainly in faeces [52]. Among the isolated Enterobacteriaceae, the species $S$. sonnei had the highest abundance (198 CFU/100 $\mu \mathrm{L}$ ) amongst all type of water sampled. This may be related to their ability to multiply more rapidly on one hand, and to the presence of environmental factors favourable to their growth on the other hand. According to Chloé [53], the Shigella species are of higher relative frequency in the environment than in human faeces and urine.

\subsection{Antibiotic susceptibility to the considered Enterobacteriaceae}

\subsubsection{Inhibition diameters}

The diameters of inhibition of the antibiotics varied according to the tested bacterial species and the type of water where it was isolated (Table 2). No inhibition diameter was observed against Ciprofloxacin, Ticarcillin, Piperacillin/tazobactam, Norfloxacin, Fosfomycin, Gentamycin, Ofloxacin, Amoxicillin+clavulanic acid and 
Sulphamethazole/trimethoprim in the presence of $E$. cloacae species isolated from groundwater. Ticarcillin does not show any inhibition diameter against $C$. freundii species isolated in surface water. However, when this species was isolated in groundwater, the same result was noted in the presence of Amoxicillin, Ticarcillin, Piperacillin/tazobactam, Cefepim, Fosfomycin, Cefuroxim and Sulphamethazole/trimethoprim (Table 2). For S. sonnei isolated from groundwater, no inhibition diameter was noted in the presence of Sulphamethazole/trimethoprim, Cefuroxim, Amoxicillin+clavulanic acid, Ofloxacin, Gentamycin, Fosfomycin, Ticarcillin and Piperacillin/tazobactam (Table 2). The same was noted for $S$. typhi isolated from surface water in the presence of Ticarcillin and Piperacillin/tazobactam, and also from groundwater in the presence of Piperacillin/tazobactam, Piperacillin, Fosfomycin, Gentamycin, Cefoxitim, Cefuroxim and Sulphamethazole/trimethoprim (Table 2).

However, it should be noted that some antibiotics have presented the greatest diameters of inhibition to bacterial species depending on the type of water where they are isolated. Against the species isolated in wastewater, the antibiotics with a larger diameter of inhibition are: Imipenem $(14.33 \mathrm{~mm})$ in the presence of E. cloacae; Sulphamethazole/trimethoprim (19.7 mm) in the presence of $S$. sonnei; and Gentamycin (17.17 mm) in the presence of $S$. typhi (Table 2). For species isolated from groundwater, there are Ceftriaxon (24.50 mm), Gentamycin (23 mm) and Amikacin (22 mm) in the presence of $C$. freundii; and Imipenem $(16.50 \mathrm{~mm}$ ) in the presence of $S$. sonnei (Table 2). With respect to the cells species isolated from surface water, there are Imipenem $(18.78 \mathrm{~mm})$ in the presence of $C$. freundii; and Amikacin (17.67 $\mathrm{mm}$ ) in the presence of $S$. sonnei (Table 2).

Table 2 Different inhibition diameters of each antibiotic with the different types of water for each bacterial species (resistance (R), intermediate (I) and sensitive (S))

\begin{tabular}{|c|c|c|c|c|c|c|}
\hline \multirow{3}{*}{$\begin{array}{l}\quad \text { (A) } \\
\text { Antibiotics } \\
\text { (mcg) }\end{array}$} & \multicolumn{6}{|c|}{ Type of water sampled, bacterial species tested and inhibition diameters (mm) } \\
\hline & \multicolumn{3}{|c|}{ E. cloacae } & \multicolumn{3}{|c|}{ C. freundii } \\
\hline & $\begin{array}{c}\text { Surface } \\
\text { water }\end{array}$ & $\begin{array}{l}\text { Waste- } \\
\text { water }\end{array}$ & $\begin{array}{c}\text { Ground- } \\
\text { water }\end{array}$ & $\begin{array}{c}\text { Surface } \\
\text { water }\end{array}$ & $\begin{array}{l}\text { Waste- } \\
\text { water }\end{array}$ & $\begin{array}{c}\text { Ground- } \\
\text { water }\end{array}$ \\
\hline \multicolumn{7}{|l|}{$\beta$-lactams } \\
\hline $\mathrm{AX}(30)$ & $6.02 \pm 3.3^{\mathrm{R}}$ & $8.83 \pm 3.13^{R}$ & $10.00 \pm 1.4^{R}$ & $7.11 \pm 5.64 \mathrm{R}$ & $7.50 \pm 4.4^{\mathrm{R}}$ & $0.00 \pm 0.00^{R}$ \\
\hline MEM (10) & $7.23 \pm 5.35^{\mathrm{R}}$ & $10.00 \pm 2.1^{\mathrm{R}}$ & $10.00 \pm 1.4^{\mathrm{R}}$ & $15.11 \pm 4.6^{\mathrm{R}}$ & $10.50 \pm 3.7^{R}$ & $10.50 \pm 4.9^{R}$ \\
\hline TIC (75) & $1.66 \pm 2.5^{\mathrm{R}}$ & $4.67 \pm 5.28^{\mathrm{R}}$ & $0.00 \pm 0.00^{\mathrm{R}}$ & $0.00 \pm 0.00^{\mathrm{R}}$ & $4.17 \pm 5.0^{\mathrm{R}}$ & $0.00 \pm 0.00^{R}$ \\
\hline TPZ (40) & $2.33 \pm 1.9^{\mathrm{R}}$ & $3.67 \pm 4.59 \mathrm{R}$ & $0.00 \pm 0.00^{R}$ & $2.56 \pm 3.17 \mathrm{R}$ & $3.00 \pm 4.8^{R}$ & $0.00 \pm 0.00^{R}$ \\
\hline PRL (75) & $7.21 \pm 4.1^{\mathrm{R}}$ & $11.33 \pm 4.5^{\mathrm{R}}$ & $10.50 \pm 0.7 \mathrm{R}$ & $10.00 \pm 6.1^{R}$ & $9.17 \pm 5.0^{\mathrm{R}}$ & $9.50 \pm 2.21^{R}$ \\
\hline FEP (10) & $5.40 \pm 2.6^{\mathrm{R}}$ & $4.67 \pm 5.28^{R}$ & $8.50 \pm 0.71^{\mathrm{R}}$ & $5.89 \pm 7.36^{\mathrm{R}}$ & $8.17 \pm 4.1^{\mathrm{R}}$ & $0.00 \pm 0.00^{\mathrm{R}}$ \\
\hline FOX (10) & $6.37 \pm 4.4^{\mathrm{R}}$ & $9.50 \pm 1.87^{R}$ & $11.50 \pm 0.7^{\mathrm{R}}$ & $9.22 \pm 5.43^{R}$ & $7.83 \pm 1.7^{\mathrm{R}}$ & $15.00 \pm 0.0^{\mathrm{R}}$ \\
\hline $\operatorname{AMC}(30)$ & $4.25 \pm 5.2^{\mathrm{R}}$ & $10.67 \pm 1.5^{R}$ & $0.00 \pm 0.00^{R}$ & $11.11 \pm 2.2^{R}$ & $10.33 \pm 2.5^{\mathrm{R}}$ & $7.50 \pm 2.1^{\mathrm{R}}$ \\
\hline CXM (5) & $5.91 \pm 3.0^{\mathrm{R}}$ & $6.83 \pm 3.97 \mathrm{R}$ & $8.50 \pm 0.71^{R}$ & $8.44 \pm 7.02^{R}$ & $6.83 \pm 3.8^{\mathrm{R}}$ & $0.00 \pm 0.00^{R}$ \\
\hline CAZ (30) & $6.22 \pm 4.2^{\mathrm{R}}$ & $10.83 \pm 2.6^{\mathrm{R}}$ & $9.50 \pm 3.54^{R}$ & $9.56 \pm 1.24^{\mathrm{R}}$ & $10.00 \pm 5.6^{\mathrm{R}}$ & $13.00 \pm 2.83^{\mathrm{R}}$ \\
\hline IMI (10) & $8.22 \pm 6.9^{\mathrm{R}}$ & $14.33 \pm 4.84^{\mathrm{R}}$ & $7.50 \pm 0.71^{R}$ & $18.78 \pm 3.1^{R}$ & $15.67 \pm 3.5^{\mathrm{R}}$ & $12.50 \pm 7.78^{\mathrm{R}}$ \\
\hline CRO (5) & $5.62 \pm 3.98^{R}$ & $9.67 \pm 1.51^{R}$ & $9.00 \pm 0.00^{R}$ & $6.89 \pm 6.68 \mathrm{R}$ & $8.17 \pm 1.83^{\mathrm{R}}$ & $24.50 \pm 0.71^{s}$ \\
\hline \multicolumn{7}{|l|}{ Quinolones } \\
\hline OFX (5) & $4.61 \pm 3.84^{\mathrm{R}}$ & $5.67 \pm 5.24^{R}$ & $0.00 \pm 0.00^{R}$ & $9.22 \pm 7.43^{R}$ & $12.00 \pm 2.1^{\mathrm{R}}$ & $13.00 \pm 5.66^{\mathrm{R}}$ \\
\hline NOR (10) & $5.64 \pm 4.51^{\mathrm{R}}$ & $9.83 \pm 6.52^{R}$ & $0.00 \pm 0.00^{R}$ & $9.22 \pm 8.26^{R}$ & $12.00 \pm 5.8^{\mathrm{R}}$ & $15.50 \pm 4.95^{\mathrm{R}}$ \\
\hline CIP (5) & $5.09 \pm 4.3^{\mathrm{R}}$ & $7.50 \pm 5.28^{R}$ & $0.00 \pm 0.00^{R}$ & $7.11 \pm 10.6^{\mathrm{R}}$ & $9.83 \pm 7.44^{\mathrm{R}}$ & $19.00 \pm 0.00^{\mathrm{R}}$ \\
\hline \multicolumn{7}{|c|}{ Aminoglycosides } \\
\hline $\mathrm{AK}(30)$ & $6.65 \pm 3.64^{R}$ & $10.00 \pm 5.4^{\mathrm{R}}$ & $9.00 \pm 0.00^{R}$ & $8.56 \pm 6.91^{R}$ & $11.67 \pm 4.93^{\mathrm{R}}$ & $22.00 \pm 4.24^{\mathrm{S}}$ \\
\hline $\mathrm{CN}(30)$ & $6.14 \pm 5.11^{\mathrm{R}}$ & $12.50 \pm 7.9^{R}$ & $0.00 \pm 0.00^{\mathrm{R}}$ & $7.00 \pm 9.43^{R}$ & $13.17 \pm 5.64^{\mathrm{R}}$ & $23.00 \pm 4.24^{\mathrm{S}}$ \\
\hline
\end{tabular}




\begin{tabular}{|c|c|c|c|c|c|c|}
\hline \multicolumn{7}{|c|}{ Sulfonamides+trimethoprim } \\
\hline $\mathrm{FF}(30)$ & $3.71 \pm 3.15^{\mathrm{R}}$ & $7.83 \pm 3.92^{\mathrm{R}}$ & $0.00 \pm 0.00^{\mathrm{R}}$ & $4.78 \pm 5.72^{\mathrm{R}}$ & $7.50 \pm 4.23^{\mathrm{R}}$ & $0.00 \pm 0.00^{\mathrm{R}}$ \\
\hline$F(300)$ & $6.37 \pm 4.08^{\mathrm{R}}$ & $11.00 \pm 2.6^{\mathrm{R}}$ & $9.50 \pm 0.71^{\mathrm{R}}$ & $8.78 \pm 5.54^{\mathrm{R}}$ & $10.67 \pm 2.5^{\mathrm{R}}$ & $9.50 \pm 3.54^{\mathrm{R}}$ \\
\hline SXT (25) & $5.70 \pm 4.43^{R}$ & $9.33 \pm 8.38^{R}$ & $0.00 \pm 0.00^{R}$ & $8.00 \pm 8.47^{R}$ & $12.00 \pm 3.79^{\mathrm{R}}$ & $0.00 \pm 0.00^{R}$ \\
\hline
\end{tabular}

Table 2 (continue)

\begin{tabular}{|c|c|c|c|c|c|c|}
\hline \multirow{3}{*}{$\begin{array}{l}\quad \text { (B) } \\
\text { Antibiotics } \\
\text { (mcg) }\end{array}$} & \multicolumn{6}{|c|}{ Type of water sampled; bacterial species tested and inhibition diameters (mm) } \\
\hline & \multicolumn{3}{|c|}{ S. sonnei } & \multicolumn{3}{|c|}{ S. typhi } \\
\hline & $\begin{array}{l}\text { Surface } \\
\text { water }\end{array}$ & $\begin{array}{l}\text { Waste- } \\
\text { water }\end{array}$ & $\begin{array}{l}\text { Ground- } \\
\text { water }\end{array}$ & $\begin{array}{l}\text { Surface } \\
\text { water }\end{array}$ & $\begin{array}{l}\text { Waste- } \\
\text { water }\end{array}$ & $\begin{array}{l}\text { Ground- } \\
\text { water }\end{array}$ \\
\hline \multicolumn{7}{|l|}{$\beta$-lactams } \\
\hline $\operatorname{AX}(30)$ & $6.11 \pm 4.01^{\mathrm{R}}$ & $11.00 \pm 1.55^{\mathrm{R}}$ & $10.00 \pm 0.0^{\mathrm{R}}$ & $4.00 \pm 6.06^{\mathrm{R}}$ & $7.83 \pm 4.71^{\mathrm{R}}$ & $10.00 \pm 4.2^{\mathrm{R}}$ \\
\hline MEM (10) & $14.44 \pm 4.3^{R}$ & $10.33 \pm 1.63^{R}$ & $12.00 \pm 2.8^{R}$ & $10.22 \pm 7.6^{\mathrm{R}}$ & $10.83 \pm 5.4^{\mathrm{R}}$ & $4.50 \pm 6.36^{\mathrm{R}}$ \\
\hline TIC (75) & $2.78 \pm 5.52^{\mathrm{R}}$ & $3.00 \pm 3.69^{\mathrm{R}}$ & $0.00 \pm 0.00^{\mathrm{R}}$ & $0.00 \pm 0.00^{\mathrm{R}}$ & $1.00 \pm 2.45^{\mathrm{R}}$ & $5.50 \pm 7.78^{\mathrm{R}}$ \\
\hline TPZ (40) & $1.56 \pm 3.09 \mathrm{R}$ & $2.33 \pm 4.08^{\mathrm{R}}$ & $0.00 \pm 0.00^{\mathrm{R}}$ & $0.00 \pm 0.00^{\mathrm{R}}$ & $3.00 \pm 4.65^{\mathrm{R}}$ & $0.00 \pm 0.00^{\mathrm{R}}$ \\
\hline PRL (75) & $12.11 \pm 3.89^{\mathrm{R}}$ & $10.17 \pm 2.14^{\mathrm{R}}$ & $7.00 \pm 9.90^{\mathrm{R}}$ & $4.56 \pm 4.56^{\mathrm{R}}$ & $8.67 \pm 5.13^{R}$ & $0.00 \pm 0.00^{\mathrm{R}}$ \\
\hline FEP (10) & $5.89 \pm 6.37^{\mathrm{R}}$ & $9.67 \pm 2.28^{\mathrm{R}}$ & $3.00 \pm 4.24^{\mathrm{R}}$ & $4.78 \pm 5.93^{\mathrm{R}}$ & $6.33 \pm 3.44^{\mathrm{R}}$ & $6.50 \pm 9.19^{R}$ \\
\hline IMI (10) & $13.67 \pm 2.69^{\mathrm{R}}$ & $14.83 \pm 5.08^{\mathrm{R}}$ & $16.50 \pm 0.7^{\mathrm{R}}$ & $11.11 \pm 6.74^{\mathrm{R}}$ & $11.17 \pm 4.1^{\mathrm{R}}$ & $13.50 \pm 2.1^{\mathrm{R}}$ \\
\hline FOX (10) & $5.67 \pm 4.58^{\mathrm{R}}$ & $8.33 \pm 4.84^{R}$ & $3.50 \pm 4.95^{\mathrm{R}}$ & $3.22 \pm 4.84 \mathrm{R}$ & $6.67 \pm 3.67^{\mathrm{R}}$ & $0.00 \pm 0.00^{\mathrm{R}}$ \\
\hline CRO (5) & $9.67 \pm 4.75^{\mathrm{R}}$ & $9.50 \pm 2.26^{\mathrm{R}}$ & $5.00 \pm 7.07^{\mathrm{R}}$ & $6.44 \pm 7.28^{\mathrm{R}}$ & $7.00 \pm 4.00^{\mathrm{R}}$ & $5.00 \pm 7.07^{\mathrm{R}}$ \\
\hline AMC (30) & $10.78 \pm 2.3^{\mathrm{R}}$ & $8.50 \pm 4.89^{R}$ & $0.00 \pm 0.00^{\mathrm{R}}$ & $8.22 \pm 5.59^{\mathrm{R}}$ & $8.33 \pm 2.25^{\mathrm{R}}$ & $6.50 \pm 9.19^{R}$ \\
\hline CXM (5) & $3.67 \pm 4.47^{\mathrm{R}}$ & $9.33 \pm 3.14^{\mathrm{R}}$ & $0.00 \pm 0.00^{\mathrm{R}}$ & $1.89 \pm 3.95^{\mathrm{R}}$ & $6.83 \pm 4.88^{\mathrm{R}}$ & $0.00 \pm 0.00^{\mathrm{R}}$ \\
\hline CAZ (30) & $10.11 \pm 4.46^{\mathrm{R}}$ & $18.33 \pm 5.4^{\mathrm{R}}$ & $9.50 \pm 2.12^{\mathrm{R}}$ & $7.89 \pm 4.81^{\mathrm{R}}$ & $16.17 \pm 8.0^{\mathrm{R}}$ & $10.00 \pm 1.4^{\mathrm{R}}$ \\
\hline \multicolumn{7}{|c|}{ Aminoglycosides } \\
\hline CIP (5) & $15.11 \pm 11.0^{\mathrm{R}}$ & $8.33 \pm 6.74^{\mathrm{R}}$ & $9.00 \pm 12.7^{\mathrm{R}}$ & $12.33 \pm 10.1^{\mathrm{R}}$ & $8.67 \pm 6.28^{\mathrm{R}}$ & $4.50 \pm 6.3^{\mathrm{R}}$ \\
\hline OFX (5) & $11.89 \pm 3.22^{\mathrm{R}}$ & $10.50 \pm 4.4^{\mathrm{R}}$ & $0.00 \pm 0.00^{\mathrm{R}}$ & $5.11 \pm 8.58^{R}$ & $7.83 \pm 4.58^{\mathrm{R}}$ & $7.50 \pm 10.6^{\mathrm{R}}$ \\
\hline NOR (10) & $16.22 \pm 6.28^{\mathrm{R}}$ & $8.50 \pm 4.32^{R}$ & $7.50 \pm 10.6^{\mathrm{R}}$ & $9.00 \pm 9.33^{R}$ & $9.83 \pm 6.85^{\mathrm{R}}$ & $13.00 \pm 2.8^{\mathrm{R}}$ \\
\hline \multicolumn{7}{|l|}{ Quinolones } \\
\hline AK (30) & $17.67 \pm 2.24^{\mathrm{S}}$ & $13.50 \pm 4.89^{\mathrm{R}}$ & $2.50 \pm 3.54^{\mathrm{R}}$ & $10.00 \pm 6.48^{\mathrm{R}}$ & $17.00 \pm 4.34^{\mathrm{S}}$ & $12.50 \pm 2.12^{\mathrm{R}}$ \\
\hline $\mathrm{CN}(30)$ & $16.11 \pm 9.16^{\mathrm{s}}$ & $15.17 \pm 8.28^{\mathrm{s}}$ & $0.00 \pm 0.00^{\mathrm{R}}$ & $6.00 \pm 9.17^{\mathrm{R}}$ & $17.17 \pm 8.57^{s}$ & $0.00 \pm 0.00^{\mathrm{R}}$ \\
\hline \multicolumn{7}{|c|}{ Sulfonamides+trimethoprim } \\
\hline$F(300)$ & $9.89 \pm 1.83^{\mathrm{R}}$ & $11.33 \pm 3.14^{\mathrm{R}}$ & $5.00 \pm 7.07^{\mathrm{R}}$ & $8.00 \pm 4.74^{\mathrm{R}}$ & $8.83 \pm 1.47^{\mathrm{R}}$ & $6.00 \pm 8.49^{\mathrm{R}}$ \\
\hline FF $(30)$ & $8.00 \pm 2.06^{\mathrm{R}}$ & $15.33 \pm 8.29^{R}$ & $0.00 \pm 0.00^{\mathrm{R}}$ & $14.33 \pm 27.58^{\mathrm{R}}$ & $8.67 \pm 2.50^{\mathrm{R}}$ & $0.00 \pm 0.00^{\mathrm{R}}$ \\
\hline SXT (25) & $6.33 \pm 7.65^{\mathrm{R}}$ & $19.17 \pm 5.49^{\mathrm{s}}$ & $0.00 \pm 0.00^{\mathrm{R}}$ & $7.00 \pm 10.50^{\mathrm{R}}$ & $15.67 \pm 8.21^{\mathrm{s}}$ & $0.00 \pm 0.00^{\mathrm{R}}$ \\
\hline
\end{tabular}

Values represent mean value \pm standard deviation of inhibition diameter of each antibiotic used (mm) for E. cloacae and C. freundii (A); and for S. sonnei and S. typhi (B). R: Resistant; S: sensitive; AX: Amoxicillin; MEM: Meropenem; CIP: Ciprofloxacin; TIC: Ticarcillin; TPZ: Piperacillin/Tazobactam; F: Nurofurantoin; CRO: Ceftriaxon; NOR: Norfloxacin; PRL: Piperacillin; FEP: Cefepim; FF: Fosfomycin; CN: Gentamycin; FOX: Cefoxitim; OFX: Ofloxacin; AMC: Amoxicillin+clavulanic acid; AK: Amikacin; CXM: Cefuroxim; CAZ: Ceftazidim; IMI: Imipenem; SXT: Sulfamethazole/trimethoprim 
All the cells tests were harvest from the stationary growth phase. The differences noted in the inhibition diameters could not be linked to specific the metabolism to the strain of each bacterial species. Main relation exists between the bacterial metabolism and the antibiotic activity. Stokes et al. [54] describe three postulates that collectively define antibiotic efficacy in the context of bacterial metabolism: a)-antibiotics alter the metabolic state of bacteria, which contributes to the resulting death or stasis; b)-the metabolic state of bacteria influences their susceptibility to antibiotics; and c)-antibiotic efficacy can be enhanced by altering the metabolic state of bacteria.

The bacterium strains $C$. cloacae isolated from the groundwater is the only which appeared sensitive against 3 of the antibiotics tested, including one $\beta$-Lactam (Ceftriaxon) and 2 quinolones (Amikacin and Gentamycin). All the bacteria strains isolated in wastewater and surface water were resistant to all the antibiotics tested (Table 2). Environment is a vast source of new and emerging resistance genes, due to the links sometimes between the environment and gene mobilization $[55,56]$. The acquisition of genes in water habitats and the development of antibiotic resistances can occur. According to Lupo et al. [57], the acquisition of heterologous genes by lateral transfer largely facilitates the adaptive evolution of bacteria, especially under strong selective pressures. This transfer of exogenous DNA in bacteria may be mediated by plasmids, phages, transposons, genomic islands, or captation of free DNA by transformation [57]. Sengelov and Sorensen [58] indicated that in many kinds of water, plasmid transfer from a donor to a recipient cell occur, even at a low frequency, and several factors could, not only influence, but also promote gene transfer among bacteria in water environment [59].

\subsubsection{Percentage of cells inhibition}

Antimicrobial susceptibility testing showed high resistance (74.51\%) of isolated Enterobacteriaceae (E. cloacae, C. freundii, S. sonnei and S. typhi) against several antibiotics that have been used. This resistance varied from one antibiotic family to another and this was observed through the percentages of inhibition (Table 3). According to Pierre [60], Enterobacteriaceae are the bacteria that are multi-resistant to antibiotics.

In the $\beta$-lactam family which represents $60 \%$ of antibiotics used in medicine [61] all strains of isolated E. cloacae at the 17 sites were fully resistant to 8 antibiotics. The $C$. freundi strains were fully resistant to 8 antibiotics tested and sensitive to one (Ceftriaxon). S. sonnei were fully resistant to 8 antibiotics and sensitive to one (Ceftazidim). With $S$. typhi, isolated strains were fully resistant to 6 antibiotics and sensitive to two (Meropenem and Ceftazidim) (Table 3).

The low toxicity of $\beta$-lactams and the broad spectrum of action of some of them make $\beta$-lactams the most prescribed antibiotic drug class and propagation of resistance constitutes therefore a major clinical concern. It has been indicated that the bacterial resistance against $\beta$-lactams is related to the usage of the drug in clinics, both because of selection of resistant bacteria and by promoting the mobilization of the genes responsible for such resistances [62]. Similarly, the presence of antibiotics in some water environments could promote the selection of antibiotic resistant strains [63].

According to Sophie [64], Enterobacteriaceae are naturally resistant to $\beta$-lactam antibiotics because they produce $\beta$ lactamases to inhibit antibiotic; this would explain the high percentage of resistance obtained. The sensitivity rate recorded with Ceftazidim and Cefuroxim antibiotics (32\% and 17.8\%) would be due to the fact that the resistance mechanism of $S$. typhi and $S$. sonnei is acquired and therefore these species inhibit the antibiotics very little.

For the 2 aminoglycosids tested, $5.88 \%$ of the strains of each isolated species were resistant to gentamycin. $88.24 \%$ of E. cloacae and $S$. sonnei strains, $94.12 \%$ of $C$. freundii and $S$. typhi were sensitive to this antibiotic. The proportion of sensitive and resistant strains towards the Amikacin also varied (Table 3). The aminoglycosides primarily act by binding to the aminoacyl site of $16 \mathrm{~S}$ ribosomal RNA within the $30 \mathrm{~S}$ ribosomal subunit, leading to misreading of the genetic code and inhibition of translocation. They inhibit protein synthesis and contain as a portion of the molecule an aminomodified glycoside $[11,65]$. The aminoglycoside modifying enzymes produced by the bacteria would have reduced affinity of aminoglycoside molecule, impede binding to the 30S ribosomal subunit, and provide extended spectrum resistance to aminoglycosides [11, 66]. Aminoglycosides are antibiotics that are naturally sensitive to Enterobacteriaceae [60], which explains the high sensitivity rate obtained.

Of the 3 quinolones tested, all strains of E. cloacae and $C$. freundii isolated from the 17 sites were fully resistant to Norfloxacin and of Ofloxacin. The proportion of strains of the 4 isolated species and which were sensitive to quinolones varied between 5.88 and 24.54\% (Tables 3). The antibiotic that showed slight sensitivity in all species was Ciprofloxacin. Gaudreau et al. [67] showed that Enterobacteriaceae, specifically Shigella develop resistance to quinolones. RodriguezMartinez et al. [68] indicated that one of the fluoroquinolones resistance genes are of the qnr family. gnr genes encode proteins binding the bacterial DNA gyrase, thus preventing the interaction of the antibiotic with its target. Generally, the presence of these acquired genes does not confer a high level of fluoroquinolones resistance, but provides a selective 
advantage in the presence of these drugs, even at low concentrations [68]. Another acquired fluoroquinolones resistance mechanism is represented by efflux mechanisms in which the qepA gene, encodes efflux pump [25, 69]. It has been recovered from the metagenome of river sediments impacted by wastewaters [70]. According to Sophie [64], the decrease in susceptibility is due to the decrease in permeability and enzymatic inactivation; this could explain the low rate of susceptibility to quinolones observed.

Table 3 Percentage of cells resistance (R), intermediate (I) and sensitive (S) by antibiotics tested

\begin{tabular}{|c|c|c|c|c|c|c|c|c|c|c|c|c|}
\hline \multirow{5}{*}{$\begin{array}{l}\text { Antibio- } \\
\text { tics } \\
\text { family } \\
\text { (mcg) } \\
\text { AX (30) }\end{array}$} & \multicolumn{12}{|c|}{ Percentage of inhibition of antibiotics (\%) and bacterial species tested } \\
\hline & \multicolumn{3}{|c|}{ E. cloacae } & \multicolumn{3}{|c|}{ C. freundii } & \multicolumn{3}{|c|}{ S. sonnei } & \multicolumn{3}{|c|}{ S. typhi } \\
\hline & $\mathbf{R}$ & I & $\mathbf{S}$ & $\mathbf{R}$ & I & $\mathbf{S}$ & $\mathbf{R}$ & I & $\mathbf{S}$ & $\mathbf{R}$ & I & $\mathbf{S}$ \\
\hline & \multicolumn{12}{|c|}{$\beta$-lactams } \\
\hline & 100 & 0 & 0 & 100 & 0 & 0 & 100 & 0 & 0 & 100 & 0 & 0 \\
\hline MEM (10) & 100 & 0 & 0 & 82.23 & 17.77 & 0 & 94.12 & 5.88 & 0 & 88.23 & 5.88 & 5.88 \\
\hline TIC (75) & 100 & 0 & 0 & 100 & 0 & 0 & 100 & 0 & 0 & 100 & 0 & 0 \\
\hline PRL (75) & 100 & 0 & 0 & 100 & 0 & 0 & 100 & 0 & 0 & 100 & 0 & 0 \\
\hline TPZ (40) & 100 & 0 & 0 & 100 & 0 & 0 & 100 & 0 & 0 & 100 & 0 & 0 \\
\hline CRO (5) & 100 & 0 & 0 & 94.11 & 0 & 5.89 & 100 & 0 & 0 & 94.11 & 5.89 & 0 \\
\hline FEP (10) & 100 & 0 & 0 & 100 & 0 & 0 & 100 & 0 & 0 & 100 & 0 & 0 \\
\hline CXM (5) & 94.11 & 5.89 & 0 & 100 & 0 & 0 & 100 & 0 & 0 & 88.23 & 11.77 & 0 \\
\hline FOX (10) & 88.24 & 11.76 & 0 & 100 & 0 & 0 & 100 & 0 & 0 & 94.11 & 5.89 & 0 \\
\hline CAZ (30) & 100 & 0 & 0 & 100 & 0 & 0 & 76.47 & 0 & 23.53 & 76.47 & 0 & 23.53 \\
\hline IMI (10) & 82.35 & 17.65 & 0 & 88.24 & 11.76 & 0 & 94.11 & 5.89 & 0 & 100 & 0 & 0 \\
\hline \multicolumn{13}{|c|}{ Aminoglycosides } \\
\hline CN (30) & 5.88 & 5.88 & 88.24 & 5.88 & 0 & 94.12 & 5.88 & 5.88 & 88.24 & 5.88 & 0 & 94.12 \\
\hline $\mathrm{AK}(30)$ & 58.88 & 5.88 & 35.29 & 52.94 & 0 & 47.06 & 35.29 & 11.76 & 52.94 & 41.17 & 5.88 & 52.94 \\
\hline \multicolumn{13}{|c|}{ Quinolones } \\
\hline CIP (5) & 88.24 & 0 & 11.76 & 76.47 & 5.88 & 17.65 & 58.82 & 17.64 & 24.54 & 76.47 & 17.65 & 5.88 \\
\hline NOR (10) & 100 & 0 & 0 & 100 & 0 & 0 & 94.11 & 0 & 5.89 & 88.24 & 0 & 11.76 \\
\hline OFX (5) & 100 & 0 & 0 & 100 & 0 & 0 & 100 & 0 & 0 & 100 & 0 & 0 \\
\hline \multicolumn{13}{|c|}{ Sulfonamides+Trimethoprim and others } \\
\hline$F(300)$ & 88.24 & 0 & 11.76 & 100 & 0 & 0 & 94.11 & 0 & 5.89 & 100 & 0 & 0 \\
\hline FF (30) & 88.24 & 0 & 11.76 & 100 & 0 & 0 & 82.35 & 0 & 17.65 & 100 & 0 & 0 \\
\hline SXT (25) & 70.58 & 4.88 & 23.54 & 70.58 & 11.76 & 17.64 & 70.58 & 11.76 & 17.64 & 76.47 & 11.76 & 11.76 \\
\hline
\end{tabular}

AX: Amoxicillin; MEM: Meropenem; CIP: Ciprofloxacin; TIC: Ticarcillin; TPZ: Piperacillin/Tazobactam; F: Nurofurantoin; CRO: Ceftriaxone; NOR: Norfloxacin; PRL: Piperacillin; FEP: Cefepim; FF: Fosfomycin; CN: Gentamycin; FOX: Cefoxitim; OFX: Ofloxacin; AMC: Amoxicillin+clavulanic acid; AK: Amikacin; CXM: Cefuroxim; CAZ: Ceftazidim; IMI: Imipenem; SXT: Sulfamethazole/trimethoprim

For the 3 Sulfonamides+Trimethoprim tested, all strains of $C$. freundii and $S$. typhi isolated were resistant to Nurofurantoin and Fosfomycin. The proportion of resistant E. cloacae and S. sonnei strains was $88.24 \%$ and 94.11 respectively against Nurofurantoin, and 88.24 and $82.35 \%$ against Fosfomycin (Table 3). The proportion of strains sensitive to one of the 3 antibiotics of this family varied from 11.76 to $23.54 \%$ for $E$. cloacae, from 0 to $17.64 \%$ for $C$. freundii, from 5.89 to $17.65 \%$ for S. sonnei and from 0 to $11.76 \%$ for S. typhi (Table 3). Sensitivity was noted in Sulfamethazole/trimethoprim against all species (Table 3). Sulfonamides are the antibiotics to which bacteria are generally sensitive; however, in this study there was a high level of resistance. The target of sulfonamides in bacteria is 
the enzyme dihydropteroate synthase. It is involved in the bacterial synthesis of the vital coenzyme, folic acid. Sulphonamides compete with the normal substrate of the enzyme, $p$-aminobenzoic acid, at the formation of dihydropteroate, which after the addition of glutamic acid gives folic acid [71]. The decrease in membrane permeability or to the acquisition of resistant plasmids or transposons could contribute to the loss of sensitivity [28].

Many mechanisms that bacteria exhibit to protect themselves from antibiotics can be classified into four basic types [56, 57, 72]: a)-the antibiotic modification, b)-the protection of the target of antibiotic action by preventing the antibiotic from entering the cell or pumping it out faster than it can flow in, c)-the alterations in the primary site of action, and d)the production of an alternative target (usually an enzyme) that is resistant to inhibition by the antibiotic.

Multidrug-resistance has been noted in this study (Tables 2 and 3). It is known that environmental microorganisms can become multidrug-resistant. Bacteria are unique in that they acquire genes from the parent microorganism during division (vertical gene transfer), but can also acquire genes from the community at large (horizontal gene transfer) [73, 74].

\subsubsection{Comparison of the inhibition diameters of antibiotics}

The Kruskal-Wallis test was performed to compare inhibition diameters of each antibiotic of the bacterial species isolated in all the considered types of water.

Table 4 P-values of the Kruskal-Wallis test comparing the antibiotics inhibition diameters amongst bacterial species isolated in all the types of water sampled

\begin{tabular}{|c|c|c|c|c|}
\hline \multirow{2}{*}{$\begin{array}{l}\text { Antibiotics } \\
\text { (mcg) }\end{array}$} & \multicolumn{4}{|c|}{ Bacterial species } \\
\hline & E. cloacae & C. freundii & S. sonnei & S. typhi \\
\hline $\mathrm{AX}(30)$ & 0.263 & 0.224 & $0.027^{*}$ & 0.295 \\
\hline MEM (10) & 0.199 & 0.141 & 0.161 & 0.441 \\
\hline CIP (5) & 0.173 & 0.267 & 0.392 & 0.559 \\
\hline TIC (75) & 0.281 & $0.045^{*}$ & 0.506 & 0.118 \\
\hline TPZ (40) & 0.488 & 0.575 & 0.647 & 0.141 \\
\hline$F(300)$ & 0.385 & 0.953 & 0.296 & 0.877 \\
\hline CRO (5) & 0.261 & 0.078 & 0.641 & 0.979 \\
\hline NOR (10) & 0.189 & 0.497 & 0.113 & 0.821 \\
\hline PRL (75) & 0.951 & 0.648 & 0.679 & 0.128 \\
\hline FEP (10) & 0.909 & 0.283 & 0.178 & 0.910 \\
\hline FF (30) & 0.098 & 0.260 & 0.019* & 0.123 \\
\hline $\mathrm{CN}(30)$ & 0.151 & 0.100 & 0.122 & $0.045^{*}$ \\
\hline FOX (10) & 0.655 & $0.030^{*}$ & 0.310 & 0.205 \\
\hline OFX (5) & 0.101 & 0.863 & 0.053 & 0.555 \\
\hline $\operatorname{AMC}(30)$ & $0.032^{*}$ & 0.227 & 0.071 & 0.994 \\
\hline AK (30) & 0.333 & 0.078 & 0.100 & 0.078 \\
\hline CXM (5) & 0.255 & 0.221 & $0.025^{*}$ & 0.052 \\
\hline CAZ (30) & 0.713 & 0.172 & $0.021 *$ & 0.276 \\
\hline IMI (10) & $0.021^{*}$ & 0.098 & 0.675 & 0.709 \\
\hline SXT (25) & 0.250 & 0.151 & $0.008^{* *}$ & 0.203 \\
\hline
\end{tabular}

*: P<0.05; ** P<0.01; AX: Amoxicillin; MEM: Meropenem; CIP: Ciprofloxacin; TIC: Ticarcillin; TPZ: Piperacillin/Tazobactam; F: Nurofurantoin; CRO: Ceftriaxon; NOR: Norfloxacin; PRL: Piperacillin;

FEP: Cefepim; FF: Fosfomycin; CN: Gentamycin; FOX: Cefoxitim; OFX: Ofloxacin; AMC: Amoxicillin+clavulanic acid;

AK: Amikacin; CXM: Cefuroxim; CAZ: Ceftazidim; IMI: Imipenem; SXT: Sulfamethazole/trimethoprim

It is noted a significant difference $(\mathrm{P}<0.05)$ of the inhibition diameters of the antibiotics Imipenem and Amoxicillin+clavulanic acid for E. cloacae, Ticarcillin and Cefoxitim for $C$. freundii, Amoxicillin, Fosfomycin, Cefuroxim, Ceftazidim and Sulfamethazole/trimethoprim for S. sonnei, and Gentamycin for S. typhi (Table 4). 
The U test of Mann-Whitney was performed to compare the antibiotic inhibition diameters of bacterial species isolated between different types of water taken 2 by two, against the 9 antibiotics that stood out from the Kruskal test. The result is presented in Table 5. It is noted a significant difference $(\mathrm{P}<0.05)$ between the inhibition diameters of Imipenem for $E$. cloacae isolated in surface water and groundwater on one hand, and in wastewater and groundwater on the other hand. The same observation was also made between the inhibition diameters of Amoxicilin+acid clavulanic for this bacterium when isolated in wastewater and groundwater (Table 5). A difference in the behavior of $C$. freundii strains isolated from wastewater and groundwater, as well as from surface water and wastewater, was observed with respect to Ticarcillin and Cefoxitin, respectively (Table 5). Likewise, a difference in susceptibility of the S. sonnei and $S$. typhi strains depending on the biotopes is also noted with respect to Amoxicillin, Fosfomycin, Cefuroxim, Ceftazidim and Sulfamethoxazole/trimethoprim on the one hand, and Gentamycin on the other hand (Table 5).

Significant differences $(\mathrm{P}<0.05)$ in the antibiotics susceptibility appeared for 7 antibiotics between bacterial strains isolated from wastewater and those from groundwater, for 6 antibiotics between bacterial strains isolated from surface water and those from wastewater, and for 3 antibiotics between bacterial strains isolated from surface water and those from groundwater (Table 5). Most strains isolated from groundwater respond to antibiotics differently from those isolated from wastewater. The difference observed in the bacterial susceptibility against antibiotics with respect to the type ow water could be linked to the abiotic properties of the water medium. Signe et al. [75] noted some significant correlations between some physico-chemical characteristics of water and the inhibition diameters of antibiotics. Eheth et al. [29] noted that the $\mathrm{pH}$ of the water medium harboring bacterial cell significantly impacts on their antimicrobial susceptibility. It has thus been suggested that the regulation of some bacterial genes would be regulated by complex mechanisms including interactions of some abiotic water characteristics $[29,75]$.

Table 5 P-values of the Mann-Whitney test comparing the antibiotic inhibition diameters of bacterial species isolated between different types of water taken 2 by two

\begin{tabular}{|c|c|c|c|}
\hline \multirow{2}{*}{$\begin{array}{c}\text { Antibiotics } \\
\text { (mcg) }\end{array}$} & \multicolumn{3}{|c|}{ Types of water taken 2 by two and bacterial species considered } \\
\hline & $\begin{array}{c}\text { Surface water } \\
\text { and } \\
\text { Wastewater }\end{array}$ & $\begin{array}{c}\text { Wastewater } \\
\text { and } \\
\text { Groundwater }\end{array}$ & $\begin{array}{c}\text { Surface water } \\
\text { and } \\
\text { Groundwater }\end{array}$ \\
\hline \multicolumn{4}{|l|}{ E. cloacae } \\
\hline IMI (10) & 0.070 & $0.044^{*}$ & $0.030 *$ \\
\hline $\operatorname{AMC}(30)$ & 0.067 & $0.042^{*}$ & 0.083 \\
\hline \multicolumn{4}{|l|}{ C. freundii } \\
\hline TIC (75) & $0.023^{*}$ & 0.252 & 1.000 \\
\hline FOX $(10)$ & 0.120 & $0.038^{*}$ & $0.032^{*}$ \\
\hline \multicolumn{4}{|l|}{ S. sonnei } \\
\hline $\mathrm{AX}(30)$ & $0.040^{*}$ & $0.042^{*}$ & 0.134 \\
\hline $\mathrm{FF}(30)$ & 0.057 & $0.042^{*}$ & $0.032^{*}$ \\
\hline CXM (5) & $0.025^{*}$ & $0.039 *$ & 0.275 \\
\hline CAZ (30) & $0.010^{*}$ & 0.064 & 0.632 \\
\hline SXT (25) & $0.006^{* *}$ & $0.044^{*}$ & 0.273 \\
\hline \multicolumn{4}{|l|}{ S. typhi } \\
\hline $\mathrm{CN}(30)$ & $0.034^{*}$ & 0.317 & 0.367 \\
\hline
\end{tabular}

In addition, the astounding number of bacterial cells in the water systems provide an immense genetic variability, and opportunities for mutations, rearrangements and horizontal gene transfer. Thus, new resistance factors likely appear regularly. Resistance factors are generally associated with some fitness cost. This cost may be particularly large for genes providing novel resistance functions for a bacterium, as their expression may not be sufficiently fine-tuned and 
their products may interfere with other cellular functions. Thus, novel resistance genes will be selected against unless there is a relatively strong selection pressure to maintain them [76, 77].

\section{Conclusion}

The Enterobacteriaceae E. cloacae, C. freundii, S. sonnei and S. typhi isolated from waster, surface water and groundwater in the Yaounde town are resistant to $\beta$-lactams, quinolones and sulfonamides, and sensitive to aminoglycosides. The inhibition diameters of antibiotic and the bacterial susceptibility against antibiotics with respect to the type of water. The susceptibility to antibiotics of Enterobacteriaceae may be linked to a complex mechanism and would be impacted by many factors. This may include the cells intrinsic properties as well as the characteristics of the environment harboring them. The regulation of some bacterial genes acting against antibiotics would be controlled by complex mechanisms including interactions of some abiotic water characteristics. It appears that the multiple uses of antibiotics in hospitals and probably in human communities can cause multidrug resistance for bacteria. This represents a health risk for humans and the aquatic environment. A control should be established in their use in hospitals and in homes, as well as tertiary treatment at the outlet of wastewater treatment plants.

\section{Compliance with ethical standards}

\section{Acknowledgments}

A Manouore Njoya, Y Poutoum and EB Mouafo Tamnou carried out the water sampling in the field. CS Metsopkeng, JS Heth, OV Noah Ewoti, A Tamsa Arfao and LM Moungang carried out physicochemical and bacteriological analysis as well as data analysis. S Chinche Belengfe improved the english language of the manuscript. PA Nana, E Masseret and T SimeNgando supplied some reagents and laboratory equipment and were also involved in the manuscript writing. All the study was supervised by M Nola.

\section{Disclosure of conflict of interest}

None conflict of interest to declare. The manuscript has not been previously submitted or published in other journal and is not being considered for publication elsewhere.

\section{References}

[1] Savadago M, Boubkeri Y. Isolation and study of some pathogenic enterobacteria in the wastewater of Oued Boumerzoug in Constantine. [Master in General Microbiology and Molecular Biology of Microorganisms]. ALGERIE: University of Mentouri Brothers Constantine. 2016.

[2] Galvin S, Boyle F, Hickey P, et al. Enumeration and characterization of antimicrobial-resistant Escherichia coli bacteria in effluent from municipal, hospital, and secondary treatment facility sources. Applied and Environmental Microbiology. 2010; 76(14): 4772-4779.

[3] Harris S, Morris C, Morris D, et al. Antimicrobial resistant Escherichia coli in the municipal wastewater system: Effect of hospital effluent and environmental fate. Science of the Total Environment. 2014; 468 à 469(0): 10781085.

[4] Garcia-Armisen T, Vercammen K, Passerat J, et al. Antimicrobial resistance of heterotrophic bacteria in sewage contaminated rivers. Water Research. 2011; 45(2): 788-796.

[5] Garcia-Armisen T, Anzil A, Cornelis P, et al. Identification of antimicrobial resistant bacteria in rivers: insights into the cultivation bias. Water Research. 2013; 47(14): 4938-4947.

[6] Sidrach-Cardona R, Hijosa-Valsero M, Marti E, et al. Prevalence of antibiotic-resistant fecal bacteria in a river impacted by both an antibiotic production plant and urban treated discharges. Science of the Total Environment. 2014; 488-489: 220-227.

[7] Hijosa-Valsero M, Fink G, Schlusener MP, et al. Removal of antibiotics from urban wastewater by constructed wetland optimization. Chemosphere. 2011; 83(5): 713-719.

[8] Sidrach-Cardona R, Bécares E. Fecal indicator bacteria resistance to antibiotics in experimental constructed wetlands. Ecological Engineering. 2013; 50: 107-111. 
[9] Kahne D, Leimkuhler C, Lu W, et al. Glycopeptide and lipoglycopeptide antibiotics. Chemical Reviews. 2005; 105(2): 425-448.

[10] Yoneyama H, Katsumata R. Antibiotic resistance in bacteria and its future for novel antibiotic development. Bioscience, Biotechnology, and Biochemistry. 2006; 70(5): 1060-1075.

[11] Kapoor G, Saigal S, Elongavan A. Action and resistance mechanisms of antibiotics: A guide for Clinicians. Journal of Anaesthesiology Clinical Pharmacology. 2017; 33(3): 300-305.

[12] Li J, Xie S, Ahmed S, et al. Antimicrobial activity and resistance: Influencing factors. Frontiers in Pharmacology. 2017; 8: 364-372.

[13] Brauner A, Fridman 0, Gefen 0, et al. Distinguishing between resistance, tolerance and persistence to antibiotic treatment. Nature Reviews Microbiology. 2016; 14(15): 320-330.

[14] CDC (Centers for diseases Control and prevention). About antibiotic resistance [Internet]. 2021 (Cited 2021 May 19].

[15] Toukam M, Lyonga EE, Assoumou MCO, et al. Quinolone and fluoroquinolone resistance in Enterobacteriaceae isolated from hospitalised and community patients in Cameroon. Journal of Medicine and Medical Sciences. 2010; 1(10): 490-494.

[16] Gniadkowski M. Evolution of extended-spectrum beta-lactamases by mutation. Clinical Microbiology and Infectious. 2008; 14(1): 11-32.

[17] Davies J, Davies D. Origins and evolution of antibiotic resistance. Microbiology and Molecular Biology Reviews. 2010; 74(3): 417-433.

[18] Marathe R, Guan Z, Anandalakshmi R, et al. Study of Arabidopsis thaliana resistome in response to cucumber mosaic virus infection using whole genome microarray. Plant Molecular Biology. 2004; 55(4): 501-520.

[19] Beutler B, Crozat K, Koziol JA, et al. Genetic dissection of innate immunity to infection: the mouse cytomegalovirus model. Current Opinion in Immunology. 2005; 17(1): 36-43.

[20] Wright Gerard D. The antibiotic resistome: the nexus of chemical and genetic diversity. Nature Reviews Microbiology. 2007; 5(3): 175-186.

[21] Ogawara HN, Kawamura T, Kudo KI, et al. Distribution of $\beta$-lactamases in Actinomycetes. Antimicrobial Agents and Chemotherapy. 1999; 435(12): 3014-3017.

[22] Roberts S, Zembower T. Global increases in antibiotic consumption: a concerning trend for WHO targets. Lancet Infectious Diseases. 2021; 21(1): 10-11.

[23] D'Costa VM, King CE, Kalan L, et al. Antibiotic resistance is ancient. Nature. 2011; 477(7365): $457-461$.

[24] Kulkarni HM, Nagaraj R, Jagannadham MV. Protective role of E. coli outer membrane vesicles against antibiotics. Microbiology Research. 2015; 181: 1-7.

[25] Li XZ, Plesiat P, Nikaido H. The challenge of efflux-mediated antibiotic resistance in Gram negative bacteria. Clinical Microbiology Reviews. 2015; 28(2): 337-418.

[26] Dyar OHNQ, Trung NW, Phuc HD, et al. High prevalence of antibiotic resistance in commensal Escherichia coli among children in rural Vietnam. BMC Infectious Diseases. 2012; 12(92): 92-99.

[27] Machado E, Coque TM, Cantón R, et al. Commensal Enterobacteriaceae as reservoirs of extended spectrum bêtalactamases, integrons, and sulgenes in Portugal. Antimicrobials Resistance and Chemotherapy. 2013; 4(80): 1-7.

[28] Chelkia H, Gueriani A. Abiotic factors and bacterial sensitivity/resistance to antibiotics: impact of $\mathrm{pH}$ and salinity. [Master in Biological Sciences]. Bouira : AkliMohand Oulhadj-Bouira University. 2019.

[29] Eheth JS, Lontsi DC, Nana PA, et al. Less effect of well physicochemical properties on the antimicrobial susceptibility Pseudomonas aeruginosa isolated in equatorial region of Central Africa. Applied Water Science. 2019; 9: 30-38.

[30] WHO (World Health Organization). Global water, sanitation and hygiene: annual report 2018 [Internet]. 2019 License: CC BY-NC-SA 3.0 IGO [cited 2021 June 15].

[31] Magana-Arachchi DN, Wanigatunge RP. Ubiquitous waterborne pathogens. Waterborne Pathogens. 2020; 15-42. 
[32] Cabral JPS. Water Microbiology: Bacterial pathogens and water. International Journal Environmental Research and Public Health. 2010; 7(10): 3657-3703.

[33] Saxena G, Bharagava RN, Kaithwas G, et al. Microbial indicators, pathogens and methods for their monitoring in water environment. Journal of Water and Health. 2015; 13(2): 319-339.

[34] Hayward C, Ross KE, Brown MH, et al. Water as a source of antimicrobial resistance and healthcare-associated infections. Pathogens. 2020; 9(8): 667.

[35] Ouguéné ELM. The city of Yaounde: an active linguistic volcano. Sens-Dessous. 2018; 1(21): 91-103.

[36] Rodier J, Legube B, Merlet N, et al. Water analysis: natural water, waste water, sea water. 9th ed. Paris: Technical and engineering, Dunod. 2009.

[37] APHA (American Public Health Association). Standard Methods for the Examination of Water and Wastewater. 22th ed. Washington, DC. 2012.

[38] Grohs P, Tillecovidin B, Caumont-Prim A, et al. Comparison of five media for detection of extended-spectrum Beta-Lactamase by use of the wasp instrument for automated specimen processing. Journal of Clinical Microbiology. 2013; 51(8): 2713-2716.

[39] Adam Salim WI. Contamination of drinking water by coliform bateria in Kassala City-Sudan. [Master Science in Microbiology]. Khartoum: University of Khartoum. 2002.

[40] Sereia MJ, Perdoncini MRFG, Março PH, et al. Techniques for the evaluation of microbiological quality in honey: Honey Analysis, Vagner de Alencar Arnaut de Toledo, IntechOpen [Internet]. 2017.

[41] Chouhan S. Recovery of Salmonella and Shigella isolates from drinking water. European Journal of Experimental Biology. 2015; 5(7): 49-61.

[42] Mahagamage MGYL, Pathirage MVSC, Manage PM. Contamination status of Salmonella spp., Shigella spp. and Campylobacter spp. in surface and groundwater of the Kelani river basin, Sri Lanka. Water. 2020; 12 (8): 2187.

[43] Kaiser G. Isolation and Identification of Enterobacteriaceae and Pseudomonas, Part 1 [Internet]. 2021 [cited 2021 May 24].

[44] Holt JG, Krieg NR, Sneath PHA, et al. Bergey's Manual of determinative bacteriology. 9th ed. Lippincott: Williams and Wilkins. 2000.

[45] Soussy CJ, Bonnet R, Caron F, et al. Antibiogram Committee of the French Microbiology Society [Internet]. 2012 [cited 2021 March 25].

[46] Abulhamd A. Genetic diversity and antimicrobial susceptibility of motile aquatic Aeromonads. International Journal of Chemical Engineering and Applications. 2010; 1(1): 90-95.

[47] Jean-Pierre B, Caron F, Cattoen C, et al. Antibiogram Committee of the French Microbiology Society [Internet]. 2020 [cited 2021 April 21st].

[48] Merhabi F, Amine H, Halwani J. Assessment of the surface water quality of the Kadicha River. Journal of Librarianship and Information Science. 2019; 20(1): 10-34.

[49] Balloy MP, Katond JP, Hanocq P. Assessment of the physico-chemical and bacteriological quality of well water in the informal settlement of Luwowoshi (DR Congo). Tropicultura. 2019; 37(2): 627-641.

[50] Diane AMY, Ange AT, Bertrand ZZ, et al. Evaluation of the physico-chemical and bacteriological quality of groundwater and health risks in some districts of Yaounde VII, Cameroon. International Journal of Biological and Chemical Sciences. 2020; 14(5): 1902-1920.

[51] Noah OVE, Moungang LM, Djeala RM, et al. An evaluation of the abundance dynamics of some sporulating bacteria in the rainwater of the city of Yaounde (Central Africa). Cameroun Journal of Biology and Biochemical Sciences. 2021; 29(2): 1-15.

[52] Bertrand X. Multi-antibiotic resistant bacteria in wastewater systems: evaluation of the role of the wastewater system in the epidemiology of ESBL producing Escherichia coli. ANSES - Research Papers. Health, Environment, Work, ANSES 2018. HAL Id: anses-01692101.

[53] Chloé B. Shigellosis: a new STI? [Doctorate in Medicine]. France: University of Bordeaux. 2019.

[54] Stokes JM, Lopatkin AJ, Lobritz MA, et al. Bacterial metabolism and antibiotic efficacy. Cell Metabolism. 2019; 30(2): 251-259. 
[55] Perron GG, Whyte L, Turnbaugh PJ, et al. Functional characterization of bacteria isolated from ancient arctic soil exposes diverse resistance mechanisms to modern antibiotics. PLOS ONE. 2015; 10(3): 533-547.

[56] Perry J, Waglechner N, Wright G. The prehistory of antibiotic resistance. Cold Spring Harbor Perspectives in Medicine. 2021; 6(6): 197-208.

[57] Lupo A, Coyne S, Berendonk TU. Origin and evolution of antibiotic resistance: the common mechanisms of emergence and spread in water bodies. Frontiers in Microbiology. 2012; 3(18): 1-13.

[58] Sengelov G, Sorensen SJ. Methods for detection of conjugative plasmid transfer in aquatic environments. Current Microbiology. 1998; 37(4): 274-280.

[59] Taylor NG, Verner-Jeffreys DW, Baker-Austin C. Aquatic systems: maintaining, mixing and mobilizing antimicrobial resistance? Trends in Ecology and Evolution. 2011; 26(6): 278-284.

[60] Pierre P. Multiresistant bacteria in the environment: research in the effluents of the city of Toulouse. [Doctorate in Pharmacy]. France: University of Limoges. 2011.

[61] Ayad QMA. Antibiotic resistance in pre-hospital urban water considered in a hydrological continuum. [Dissertation in waterborne pathogens -Health and Environment]. France: University of Montpellier. 2017.

[62] Bush K, Fisher JF. Epidemiological expansion, structural studies, and clinical challenges of new beta-lactamases from gram- negative bacteria. Annual Review of Microbiology. 2011; 65: 455-478.

[63] Pérez-Parada A, Aguera A, Gomez-Ramos Mdel M, et al. Behavior of amoxicillin in wastewater and river water: identification of its main transformation products by liquid chromatography/electrospray quadrupole time-offlight mass spectrometry. Rapid Communications in Mass Spectrometry. 2011; 25(6): 731-742.

[64] Sophie Z. Bacterial resistance to antibiotics: occurrence and control strategies. [Doctorate in Pharmacy]. France: University of Limoges. 2014.

[65] Mingeot-Leclercq MP, Glupczynski Y, Tulkens PM. Aminoglycosides: activity and resistance. Antimicrobial Agents and Chemotherapy. 1999; 43(4): 727-737.

[66] Strateva T, Yordanov D. Pseudomonas aeruginosa - A phenomenon of bacterial resistance. Journal of Medical Microbiology. 2009; 58(9): 1133-1148.

[67] Gaudreau C, Pilon PA, Cornut G, et al. Shigella flexneri with Ciprofloxacin resistance and reduced Azithromycin susceptibility. Emerging Infectious Diseases. 2016; 22(11): 2016-2018.

[68] Rodriguez-Martinez JM, Cano ME, Velasco C, et al. Plasmid-mediated quinolone resistance: an update. Journal of Infection and Chemotherapy. 2011; 17(2): 149-182.

[69] Perichon B, Courvalin P, Galimand M. Transferable resistance to aminoglycosides by methylation of G1405 in $16 \mathrm{~S}$ rRNA and to hydrophilic fluoroquinolones by QepA-mediated efflux in Escherichia coli. Antimicrobial Agents and Chemotherapy. 2007; 51(7): 2464-2469.

[70] Cummings DE, Archer KF, Arriola DJ, et al. Broad dissemination of plasmid-mediated quinolone resistance genes in sediments of two urban coastal wetlands. Environmental Science and Technology. 2011; 45(2): 447-454.

[71] Ola Sköld. Sulfonamides and trimethoprim. Expert Review of Anti-infective Therapy. 2010; 8(1): 1-6.

[72] Hawkey PM. The origins and molecular basis of antibiotic resistance. BMJ. 1998; 317(7159): 657-660.

[73] Aminov RI. Horizontal gene exchange in environmental microbiota. Frontiers in Microbiology. 2011; 2: $158-177$.

[74] Skippington E, Ragan MA. Lateral genetic transfer and the construction of genetic exchange communities. FEMS Microbiology Reviews. 2011; 35(5): 707-735.

[75] Signe JM, Lontsi CD, Njoya AM, et al. Assessment of the potential effect of some streams properties on the isolated Aeromonas hydrophila strains susceptibility against some $\beta$-Lactams and Sulfamids. Research in Biotechnology. 2015; 6(5): 33-44.

[76] Kallmeyer J, Pockalny R, Adhikari RR. Global distribution of microbial abundance and biomass in subseafloor sediment. Proceedings of the National Academy of Sciences (USA). 2012; 109(40): 16213-16216.

[77] Bengtsson-Palme J, Kristiansson E, Larsson DGJ. Environmental factors influencing the development and spread of antibiotic resistance. FEMS Microbiology Reviews. 2018; 42(1): 68-80. 